\title{
Involvement of reactive oxygen species and caspase-dependent pathway in berberine-induced cell cycle arrest and apoptosis in C6 rat glioma cells
}

\author{
TING-CHING CHEN ${ }^{1}$, KUANG-CHI LAI ${ }^{2,3}$, JAI-SING YANG ${ }^{4}$, \\ CHING-LUNG LIAO ${ }^{5}$, TE-CHUN HSIA ${ }^{6}$, GUANG-WEI CHEN ${ }^{7}$, JEN-JYH LIN ${ }^{8}$, \\ HUI-JU LIN ${ }^{9}$, TSAN-HUNG CHIU ${ }^{10}$, YIH-JING TANG ${ }^{11}$ and JING-GUNG CHUNG ${ }^{1,12}$
}

\begin{abstract}
${ }^{1}$ Department of Biological Science and Technology, ${ }^{2}$ School of Medicine, China Medical University, Taichung;
${ }^{3}$ Department of Surgery, China Medical University Beigang Hospital, Beigang, Yunlin; ${ }^{4}$ Department of Pharmacology,

${ }^{5}$ Graduate Institute of Chinese Medical Science, China Medical University; ${ }^{6}$ Department of Internal Medicine,

China Medical University Hospital, Taichung; ${ }^{7}$ Department of Traditional Chinese Medical, Chung-Ho Memorial Hospital,

Kaohsiung Medical University, Kaohsiung; ${ }^{8}$ Division of Cardiology, Departments of ${ }^{9}$ Ophthalmology and ${ }^{10} \mathrm{OBS} / \mathrm{GYN}$,

China Medical University; ${ }^{11}$ Family Medicine Department, Taichung Veterans General Hospital;

${ }^{12}$ Department of Biotechnology, Asia University, Wufeng, Taichung, Taiwan, R.O.C.
\end{abstract}

Received January 9, 2009; Accepted March 12, 2009

DOI: 10.3892/ijo_00000299

\begin{abstract}
The cytotoxicity of berberine on C6 rat glioma cells indicated that berberine induced morphological changes and caused cell death through G2/M arrest and apoptosis. While undergoing apoptosis, there was a remarkable accumulation of $\mathrm{G} 2 / \mathrm{M}$ cells with the upregulatoin of Wee1 but it also inhibited cyclin B, CDK1 and Cdc25c that led to G2/M arrest. Along with cytotoxicity in C6 cells, several apoptotic events including mitochondrial cytochrome $c$ release, activation of caspase- $9,-3$ and -8 and DNA fragmentation were induced. Berberine increased the levels of GADD153 and GRP 78 in C6 cells based on the examination of Western blotting and this is a major hallmark of endoplasmic reticulum (ER) stress. We also found that berberine promoted the production of reactive oxygen species and $\mathrm{Ca}^{2+}$ in $\mathrm{C} 6$ cells. Western blotting assay also showed that berberine inhibited the levels of anti-apoptotic protein Bcl-2 but increased the levels of pro-apoptotic protein Bax before leading to a decrease in the levels of mitochondrial membrane potential $\left(\Delta \Psi_{m}\right)$ followed by cytochrome $c$ release that caused the activations of capase-9 and -3 for apoptotic occurrence. The caspase- $8,-9$ and -3 were activated by berberine in $\mathrm{C} 6$ cells based on the substrate solution (PhiPhiLux- $\mathrm{G}_{1} \mathrm{D}_{1}$, CaspaLux 8- $\mathrm{L}_{1} \mathrm{D}_{2}$, CaspaLux 9-
\end{abstract}

Correspondence to: Dr Jing-Gung Chung, Department of Biological Science and Technology, China Medical University, No. 91, Hsueh-Shih Road, Taichung 404, Taiwan, R.O.C.

E-mail: jgchung@mail.cmu.edu.tw

Key words: berberine, apoptosis, reactive oxygen species, mitochondria membrane potential, cytochrome $c$
$M_{1} D_{2}$ for caspase- $3,-8$ and -9 , respectively) and analyzed by flow cytometer and each inhibitor of caspase- $8,-9$ and -3 led to increase the percentage of viable $\mathrm{C} 6$ cells after exposure to berberine. This finding was also confirmed by Western blot assay which showed that berberine promoted the active form of caspase- $8,-9$ and -3 . These results demonstrate that the cytotoxicity of berberine in C6 rat glioma cells is attributable to apoptosis mainly through induced G2/M-arrested cells, in an ER-dependent manner, via a mitochondria- dependent caspase pathway regulated by Bax and Bcl-2.

\section{Introduction}

Anti-cancer agents cause anti-cancer activities through cell death by i) interfering with the processes of the cell cycle and ii) through apoptosis. It still remains to be confirmed whether or not chemotherapeutic agents induce apoptosis in cancer cells, and what is the determinant of the response of tumor cells to these agents. Glima tumor, one of the most threatening brain malignant cancers, is sensitive to anticancer chemotherapeutic reagents through either interfereing with the cell cycle or causing apoptosis. Therefore, the best strategies for chemoprevention or chemotherapy are to induce apoptosis in cancer cells. It was reported that the mitochondrial production of reactive oxygen species (ROS) seems to play a role in cell death (1) and it also known that the exogenous and endogenous $\mathrm{ROS}$, such as $\mathrm{H}_{2} \mathrm{O}_{2}$ and $\mathrm{O}^{2-}$, respectively, cause apoptosis through mitochondrial permeability transition. Other investigators also point out that some of the anti-cancer drugs can induce the generation of ROS in apoptosis $(2,3)$ and induce apoptosis through a direct mitochondrial effect leading to the activation of caspases (4).

Many cancer treatment drugs are obtained from natural plant sources and $74 \%$ of these chemotherapeutic drugs were 
discovered by investigating a folklore claim $(5,6)$. Berberine, an isoquinoline alkaloid, is present in the roots, rhizome and stem bark of Berberis aquifolium, Berberis vulgaris and Berberis aristata (7). Berberine has been reported to exhibit a wide range of biological activities such as anti-diarrheal, anti-arrhythmic and anti-tumor activities (7-10). Berberine also inhibits cyclooxygenase- 2 transcriptional activity in human colon cancer cells $(11,12)$, inhibits tumor promoting activity of teleocidin in two-stage chemical carcinogenesis on mouse skin (13), inhibits DNA topoisomerase I and II in a biochemical system $(14,15)$ and induces cell cycle arrest and apoptosis in human epidermoid carcinoma A431 cells (16). Our previous studies showed that berberine inhibits WEHI-3 leukemia cells in vivo (17), induces apoptosis in human HSC-3 oral cancer cells via simultaneous activation of the death receptor-mediated and mitochondrial pathway (18) and induces down-regulation of matrix metalloproteinase-1, -2 and -9 in human gastric cancer cells (SNU-5) in vitro (19). However, there is no information to address berberineinduced apoptosis in C6 rat glioma cells. Therefore, we investigated the inhibition of growth, proliferation and apoptosis induction in C6 cells. Our study also provides insight into the mechanism of berberine-induced apoptosis in C6 cells.

\section{Materials and methods}

Chemicals and reagents. Berberine, dimethyl sulfoxide (DMSO) and propidium iodide (PI) were purchased from Sigma Chemical (St. Louis, MO). The primary antibodies were obtained as follows: antibodies for Fas/CD95, Bax, Bcl-2, caspase-8, - 9 and -3, pro-caspase-8, -9 and -3, GADD153, GRP 78, pro-caspase-12 and 3 -actin were purchased from Cell Signaling Technology (Beverly, MA, USA); antibodies for cytochrome $c$, Cyclin B, CDK1, Wee1, Cdc25c and the secondary antibodies, which were horseradish peroxidase (HRP)-linked goat anti-mouse IgG and goat anti-rabbit IgG, were purchased from Santa Cruz Biotechnology (Santa Cruz, CA, USA). The protein assay kit was purchased from Bio-Rad (Hercules, CA, USA).

Cells, culture conditions and treatments. C6 rat glioma cells were purchased from the Food Industry Research and Development Institute (Hsinchu, Taiwan, R.O.C.). The culture medium consisted of Kaighn's modification of Ham's F-12 medium (KMHF) (Gibco Life Technologies, Gaithersburg, MD, USA), $10 \%$ fetal bovine serum (FBS) (Gibco BRL, Grand Island, NY, USA), $1 \%$ penicillin-streptomycin (100 U/ml penicillin and $100 \mu \mathrm{g} / \mathrm{ml}$ streptomycin). C6 cells were cultured as monolayers in KMHF medium and maintained in an incubator with a humidified atmosphere of $95 \%$ air and 5\% $\mathrm{CO}_{2}$ at $37^{\circ} \mathrm{C}$. In all treatments, berberine was initially dissolved in a small amount of DMSO and made up to the maximum final concentration of $0.2 \%(\mathrm{v} / \mathrm{v})$ in the complete cell culture medium. The sub-cultured cells were treated with either varying concentrations of berberine or vehicle alone $(0.2 \%$ DMSO in media) that served as control (20-22).

Assessment of cell morphology and viability. Approximately $2 \times 10^{5}$ cells/well of C6 cells were placed onto 12-well plates in
$\mathrm{KMHF}$ culture medium and incubated at $37^{\circ} \mathrm{C}$ for $24 \mathrm{~h}$ then treated individually with $0,50,100,200$ and $500 \mu \mathrm{M}$ berberine and incubated for $24 \mathrm{~h}$ or treated with $100 \mu \mathrm{M}$ berberine for $0,12,24,48$ and $72 \mathrm{~h}$. Vehicle alone (DMSO) was used as control. For cell morphological examination, cells onto the plate were directly examined and were photographed under a phase-contrast microscope. For percentage of cell viability, cells were collected, PI was added and then they were counted by flow cytometric analysis, as previously described $(20,21)$.

Determination of cell cycle and apoptosis by flow cytometry. Approximately $2 \times 10^{5}$ cells/well of C6 cells were grown in a 12 -well plate in KMHF culture medium for $24 \mathrm{~h}$ then treated individually with $100 \mu \mathrm{M}$ berberine and cells incubated at $37^{\circ} \mathrm{C}, 5 \% \mathrm{CO}_{2}$ and $95 \%$ air for $0,12,24,48$ and $72 \mathrm{~h}$. For cell cycle arrest with sub-G1 (apoptosis), isolated cells were fixed by $70 \%$ ethanol then kept at $4{ }^{\circ} \mathrm{C}$ overnight and then resuspended in PBS containing $40 \mu \mathrm{g} / \mathrm{ml}$ PI and $0.1 \mathrm{mg} / \mathrm{ml}$ RNase and $0.1 \%$ Triton X-100 in dark room for $30 \mathrm{~min}$ at $25^{\circ} \mathrm{C}$. The cells were analyzed for the cell cycle distribution, then determined using FACSCalibur instrument (BD Biosciences, San Jose, CA) equipped with CellQuest 3.3 software. The cell cycle with sub-G1 was then determined and analyzed $(20,21,23)$.

Comet assay for DNA damage. The Comet assay was used for examining the DNA damage and was done according to the procedures of Wang et al (23) with some modifications. Approximately $2 \times 10^{5}$ cells/well of C6 cells were grown in a 12-well plate in KMHF culture medium for $24 \mathrm{~h}$ then treated individually with $0,50,100$ and $200 \mu \mathrm{M}$ berberine and/or $0.5 \% \mathrm{H}_{2} \mathrm{O}_{2}$ then cells incubated at $37^{\circ} \mathrm{C}, 5 \% \mathrm{CO}_{2}$ and $95 \%$ air for $24 \mathrm{~h}$. Cells were harvested by centrifugation for the examination of DNA damage using the Comet assay as described elsewhere $(23,24)$.

DAPI staining for apoptosis. Approximately $2 \times 10^{5}$ cells/well of C6 cells were grown in a 12-well plate in KMHF culture medium for $24 \mathrm{~h}$ then treated individually with $0,50,100$ and $200 \mu \mathrm{M}$ berberine and cells incubated at $37^{\circ} \mathrm{C}, 5 \% \mathrm{CO}_{2}$ and $95 \%$ air for $48 \mathrm{~h}$. Cells were harvested from each sample for 4,6-diamidino-2-phenylindole dihydrochloride (DAPI) staining, as described previously (9). After staining, the cells were examined and were photographed under a fluorescence microscope $(20,21)$.

DNA laddering fragmentation. Approximately $1 \times 10^{6}$ cells/well of C6 cells were grown in 6-well plates and treated with 100 $\mu \mathrm{M}$ berberine for $0,3,6,12,24,48$ and $72 \mathrm{~h}$. DNA was isolated from each sample and examined in $0.8 \%$ agarose gel electrophoresis, then photographed under a fluorescence microscope, as described previously (25).

Reactive oxygen species ( $\mathrm{ROS}), \mathrm{Ca}^{2+}$ concentrations and mitochondrial membrane potential $\left(\Delta \Psi_{m}\right)$ determinations. Approximately $2 \times 10^{5}$ cells/well of C6 cells were grown in a 12 -well plate in KMHF culture medium for $24 \mathrm{~h}$ then either pretreated or not with NAC, treated individually with $100 \mu \mathrm{M}$ berberine and incubated at $37^{\circ} \mathrm{C}, 5 \% \mathrm{CO}_{2}$ and $95 \%$ air for 0 , 
a.
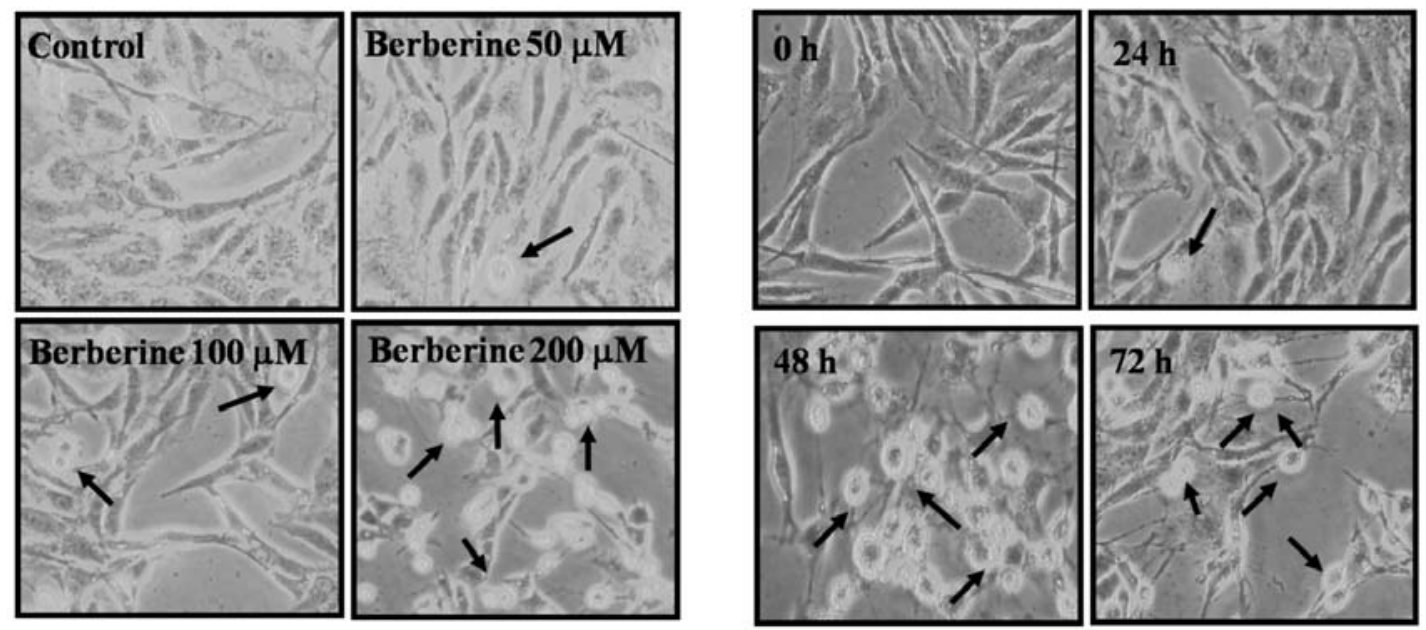

b.

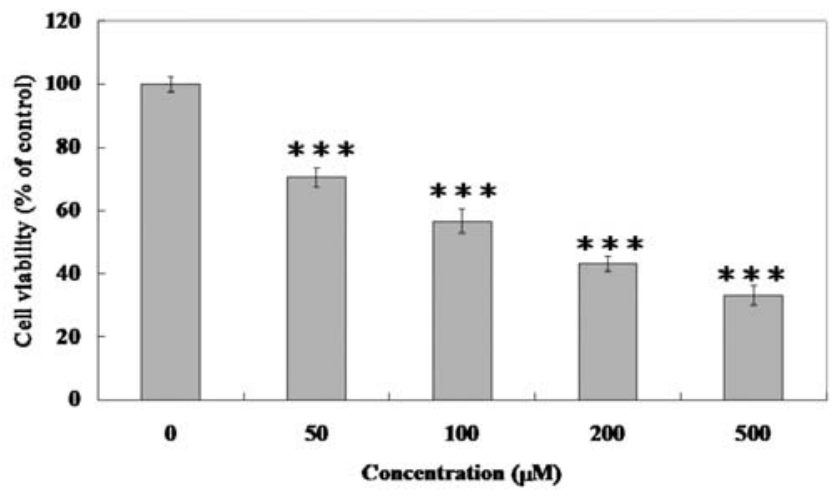

c.

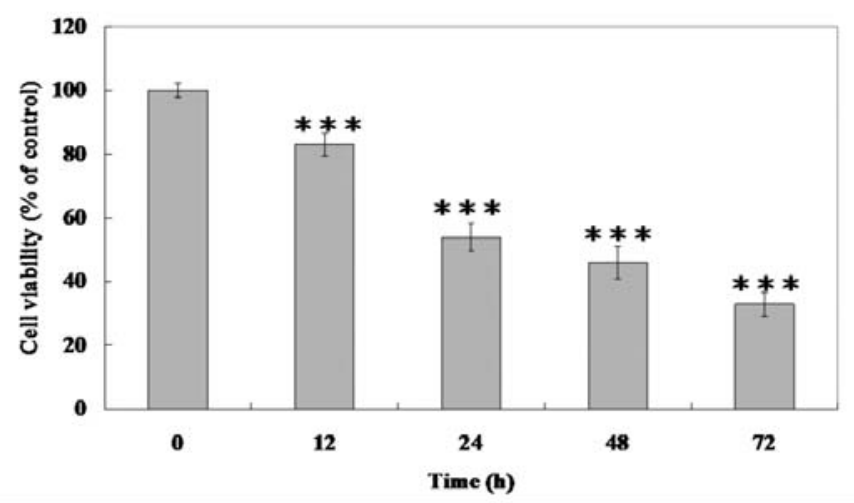

Figure 1. The effects of berberine on the morphological changes and percentage of viable C6 cells. Cells were plated in KMHF medium $+10 \%$ FBS with various concentrations of berberine for $24 \mathrm{~h}$, or treated with $100 \mu \mathrm{M}$ berberine for $0,12,24,48$ and $72 \mathrm{~h}$ and the morphological changes were examined under phase contrast microscope (a). Total percentage of viable cells dose-dependent (b) and time-dependent (c) were determined by flow cytometry. Each point is mean $\pm \mathrm{SD}$ of three experiments. ${ }^{* * *} \mathrm{P}<0.001$.

$0.25,0.5,2$ and $4 \mathrm{~h}$ to detect the changes of ROS, $\mathrm{Ca}^{2+}$ concentrations and $\Delta \Psi_{m}$. Cells were harvested by centrifugation then re-suspended in $500 \mu \mathrm{l}$ of DCFH-DA $(10 \mu \mathrm{M})$ for ROS determination, re-suspended in $500 \mu \mathrm{l}$ of Indo 1/AM $(3 \mu \mathrm{g} / \mathrm{ml})$ for $\mathrm{Ca}^{2+}$ concentrations and suspended in $500 \mu \mathrm{l}$ of $\mathrm{DiOC}_{6}(4 \mu \mathrm{mol} / 1)$ for incubation at $37^{\circ} \mathrm{C}$ for $30 \mathrm{~min}$ and analyzed by flow cytometry $(18,20,21)$.

Caspase-3, -8 and -9 activity determination by flow cytometer. Approximately $2 \times 10^{5}$ cells/well of C6 cells were grown in a 12-well plate in KMHF culture medium for $24 \mathrm{~h}$ then treated individually with $100 \mu \mathrm{M}$ berberine and incubated at $37^{\circ} \mathrm{C}$, $5 \% \mathrm{CO}_{2}$ and $95 \%$ air for $0,24,48$ and $72 \mathrm{~h}$. Cells were harvested from each sample by centrifugation and $50 \mu 1$ of $10 \mu \mathrm{M}$ each substrate solution (PhiPhiLux $-\mathrm{G}_{1} \mathrm{D}_{1}$, CaspaLux 8- $\mathrm{L}_{1} \mathrm{D}_{2}$, CaspaLux $9-\mathrm{M}_{1} \mathrm{D}_{2}$ for caspase-3, -8 and -9 , respectively) was added to the cell pellet $\left(1 \times 10^{5}\right.$ cells per sample) and cells were incubated at $37^{\circ} \mathrm{C}$ for $60 \mathrm{~min}$ in the dark, washed twice with $1 \mathrm{ml}$ of ice-cold PBS and resuspended in $1 \mathrm{ml}$ fresh PBS, as described previously $(9,10)$. 
a.

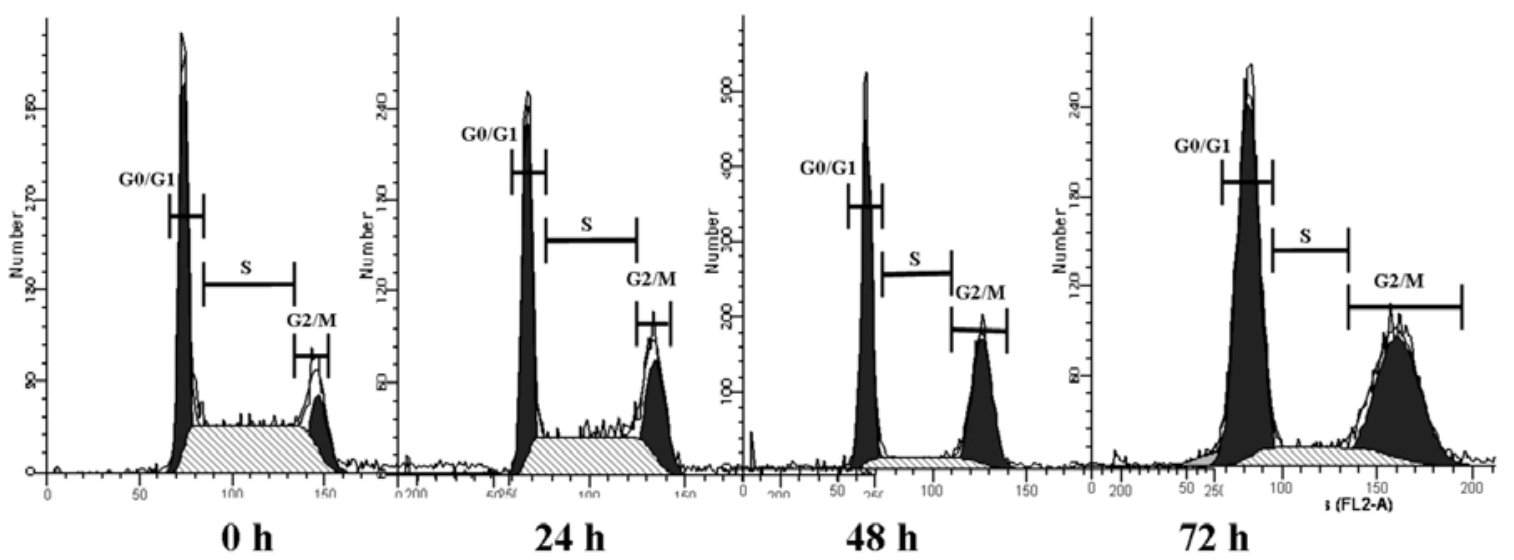

b.

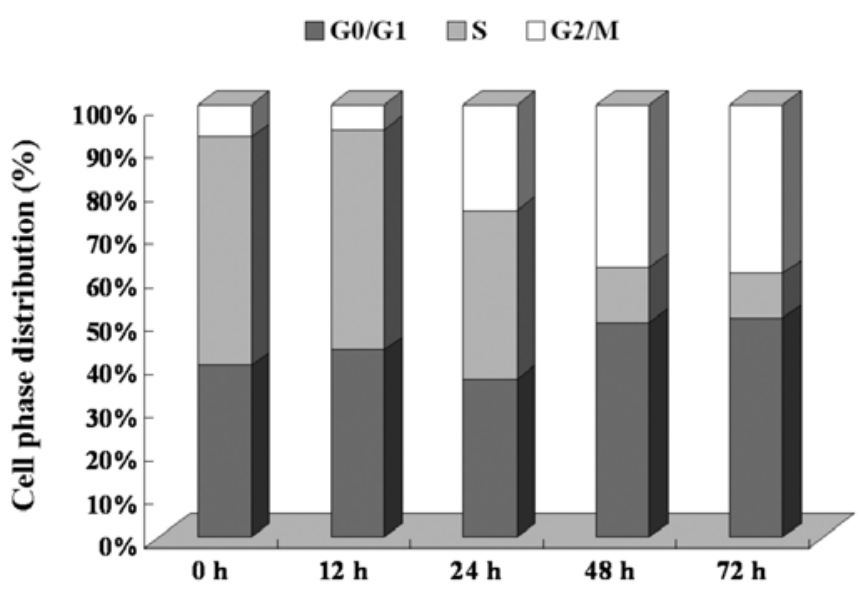

Figure 2. The effects of berberine on the cell cycle and sub-G1 group of C6 cells. Cells were plated in a 12-well plate with various concentrations of berberine for $48 \mathrm{~h}$ and the cells were analyzed for cell cycle (a) representative profiles; (b) the percentage of cell phase distribution by flow cytometry.

Caspase-3, -8 and -9 activities were determined and analyzed according to the manufacturer's instructions $(20,21,24)$.

Examination by Western blotting of cell cycle and apoptosisassociated proteins. Approximately $5 \times 10^{5}$ cells/well of C6 cells were grown in a 12 -well plate in KMHF culture medium for $24 \mathrm{~h}$ then treated individually with $100 \mu \mathrm{M}$ berberine and cells incubated at $37^{\circ} \mathrm{C}, 5 \% \mathrm{CO}_{2}$ and $95 \%$ air for $0,6,12,24,48$ and $72 \mathrm{~h}$. Cells were harvested from each sample by centrifugation for the total protein determination, and for Western blotting examination. Cyclin B, CDK1, Wee 1 and $\mathrm{Cdc} 25 \mathrm{c}$, Fas/CD95, pro-caspase-8 and -3, cytochrome $c$, pro-caspase-9, Bcl-2 and Bax, GADD153, GRP 78 and pro-caspase- 12 expression levels were examined using sodium dodecylsulfate polyacrylamide gel electrophoresis (SDS-PAGE) and Western blotting, as described previously (19-22).

\section{Results}

The effects of berberine on the morphological changes and the percentages of C6 rat glioma cells. In order to examine the cytotoxic effects of berberine, C6 cells were treated with 0 , $50,100,200$ and $500 \mu \mathrm{M}$ berberine for $24 \mathrm{~h}$ or treated with $100 \mu \mathrm{M}$ berberine for $0,12,24,48$ and $72 \mathrm{~h}$ and both cell morphological changes and cell death were assayed. The results indicated that berberine induced cell morphological changes and cell death at $>50 \mu \mathrm{M}$ and this effect is dose- and time-dependent (Fig. 1a). Based on these pilot observations, berberine caused strong cell morphological changes (Fig. 1a) and cell death induction mostly dose- (Fig. 1b) and timedependent (Fig. 1c) in the examined time periods. We selected the $100 \mu \mathrm{M}$ dose and next assessed whether the growth-inhibitory and cell death effects of berberine are accompanied by an effect on cell cycle progression and/or apoptotic cell death.

The effects of berberine on the cell cycle and sub-G1 group of C6 rat glioma cells. Berberine showed statistically significant cell cycle arrest at $100 \mu \mathrm{M}$ berberine following its treatment for $0,12,24,48$ and $72 \mathrm{~h}$ (Fig. 2a and b). At 12, 24, 48 and 72 h-treatment intervals, compared with DMSO controls, it caused an arrest of $\mathrm{G} 2 / \mathrm{M}$ phase (5 vs. 2, 22, 36 and $34 \%$ $\mathrm{P}=0.001$, respectively), which were at the expense of a strong decrease in S-phase cell population (Fig. 2b). In cell cycle and sub-G1 studies assessing whether berberine also causes apoptotic cell death, as shown in Fig. 2a, the treatment at 100-500 $\mu \mathrm{M}$ dose for 24-72 $\mathrm{h}$ resulted in a strong and statistically significant apoptotic cell death. Based on the sub-G1, it appears that increased dose of berberine led to 
a.
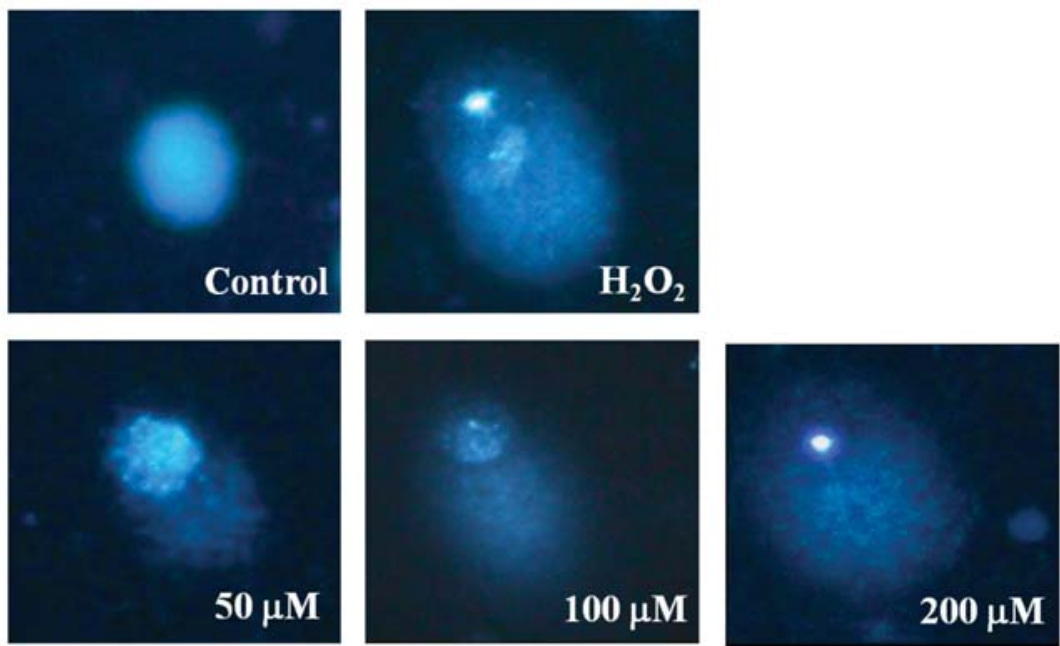

b.
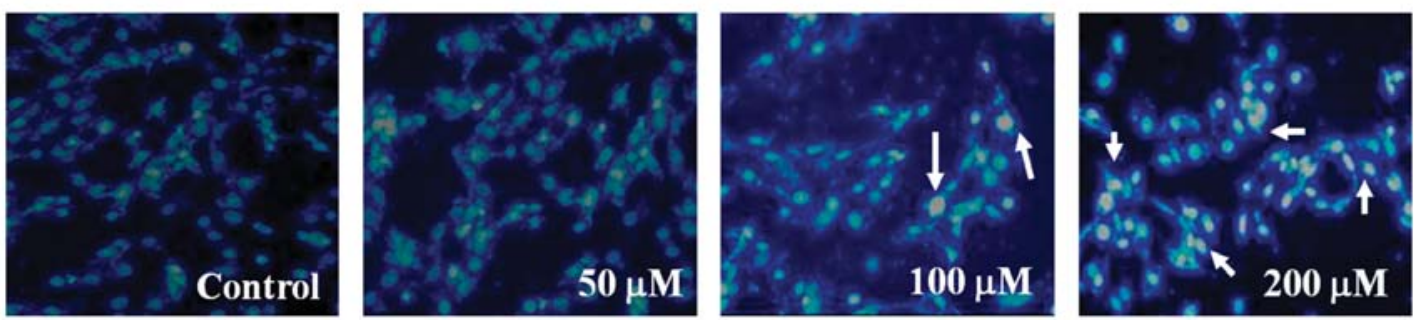

c.

Time (h)

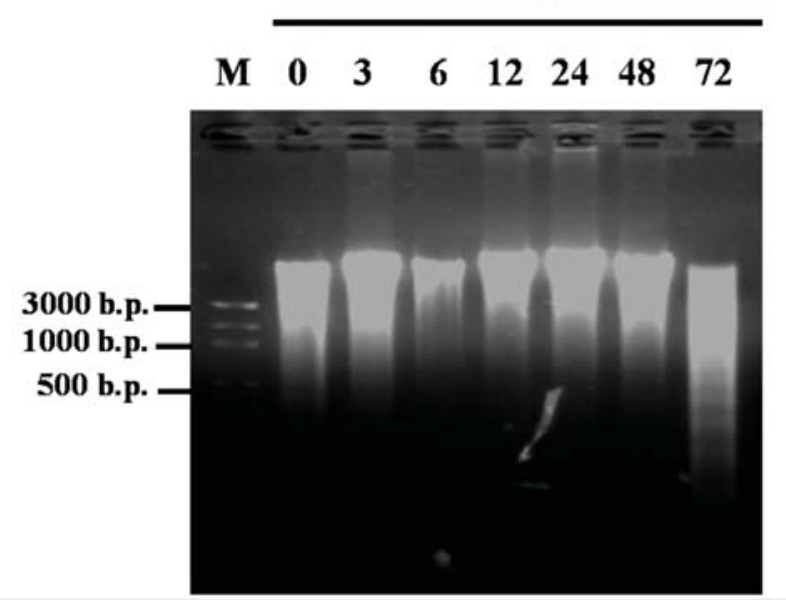

M: Marker

Figure 3. Berberine-induced DNA damage and apoptosis in $\mathrm{C} 6$ cells. Cells were incubated with various concentrations of berberine and $0.5 \% \mathrm{H}_{2} \mathrm{O}_{2}$ for $24 \mathrm{~h}$. DNA damage was determined using Comet assay (a) and apoptotic cells were determined by DAPI staining (b) and DNA gel electrophoresis (c) by fluorescence microscopy.

increase percentage of sub-G1 and this indicates that it increased the percentage of apoptosis (Fig. 2a) and these effects were time-dependent. Collectively, the results shown in Fig. 2 clearly show the cytotoxic effects of berberine on C6 cell growth inhibition and death, as well as cell cycle arrest and induction of apoptosis.

Berberine-induced DNA damage and apoptosis in C6 rat glioma cells. Although other studies have shown that berberine induced DNA damage in some cell lines, here, in order to examine whether or not berberine induced DNA damage in C6 cells, Comet assay was used and results indicated that berberine induced DNA damage based on the DNA damage tail production which is shown in Fig. 3a. Increasing the dose of berberine led to an increase of DNA damage and those effects were dose-dependent. To determine whether cytotoxic effect of berberine was due to apoptosis induction, the membrane bleeding and DNA ladder were observed in C6 cells treated with the examined dose of berberine and photographed under a fluorescence microscope. As shown in 
a.
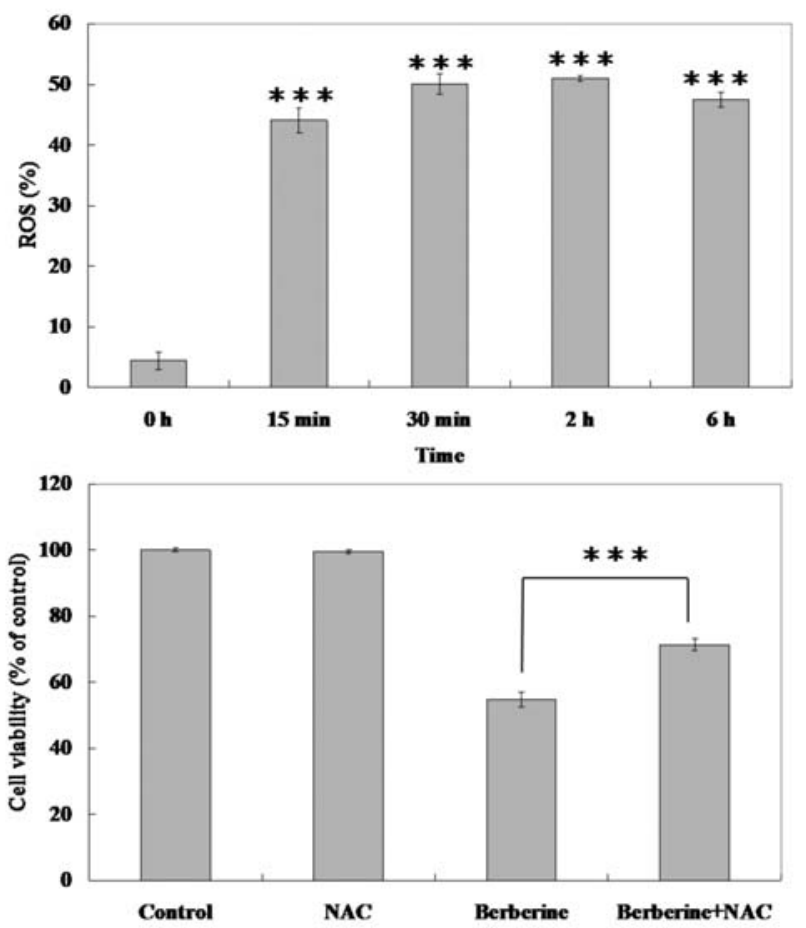

b.

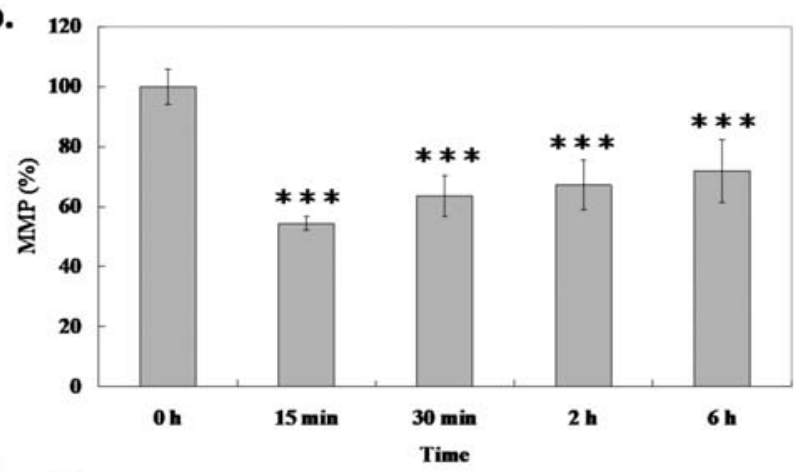

c.

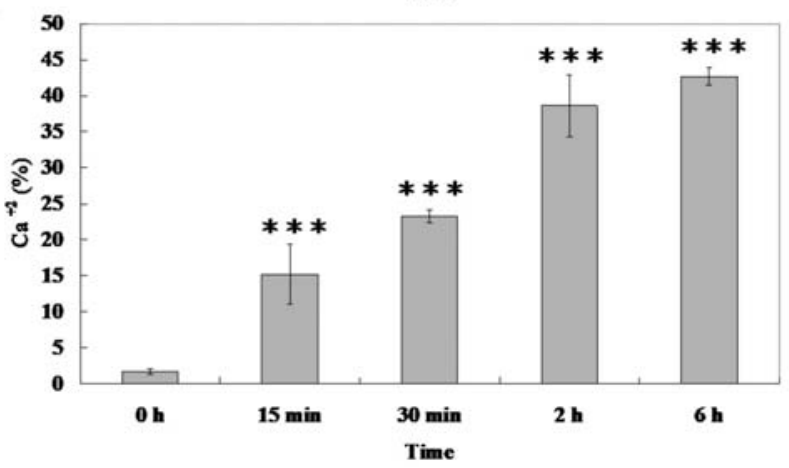

Figure 4. Berberine affects the levels of ROS, $\Delta \Psi_{m}$ and $\mathrm{Ca}^{2+}$ in $\mathrm{C} 6$ cells Cells were incubated with $100 \mu \mathrm{M}$ berberine for $0,0.25,0.5,2$ and $6 \mathrm{~h}$ and/or preteated with NAC, before stained with 2,7-dichlorodihydrofluorescein diacetate for ROS level determination and cell viability after treatment (a), stained with $\mathrm{DiOC}_{6}$ for the $\Delta \Psi_{m}$ level determination (c) and stained with Indo 1/AM for the $\mathrm{Ca}^{2+}$ level (c) determined, as described in Materials and methods. Each point is mean $\pm \mathrm{SD}$ of three experiments. ${ }^{* * *} \mathrm{P}<0.001$.

Fig. $3 b$ and $c$, the photographs from DAPI staining and DNA gel electrophoresis assays revealed that apoptotic cells were observed in berberine- treated C6 cells compared with intact control cells and this effect was dose-dependent (Fig. $3 \mathrm{~b}$ and $\mathrm{c})$.
Berberine affected the levels of reactive oxygen species (ROS) and $\mathrm{Ca}^{2+}$ and mitochondria membrane potential $\left(\Delta \Psi_{m}\right)$ in C6 cells. In order to examine whether or not berberine induced DNA damage and apoptosis in C6 cells due to the effects of ROS, $\mathrm{Ca}^{2+}$ and $\Delta \Psi_{m}$. C6 cells were pre-exposed with NAC then treated with $100 \mu \mathrm{M}$ berberine for various time periods. ROS production was analyzed and quantified by flow cytometry. The data demonstrated that berberine induced ROS production quite early and time-dependently (Fig. 4a) and pretreatment with NAC decreased the ROS after treatment with berberine. The data demonstrated that berberine induced $\mathrm{Ca}^{2+}$ production was slightly increased up to $4 \mathrm{~h}$ to produce high level of $\mathrm{Ca}^{2+}$ (Fig. 4c). The results also showed that berberine promoted the loss of mitochondrial $\Delta \Psi_{m}$ in C6 cells and this effect also was time-dependent (Fig. 4b).

Berberine affects the levels of caspase- 3, -8 and -9 activity of C6 cells. In order to examine whether or not berberine induced apoptosis in C6 cells through caspase-activation, cells were treated with or without $100 \mu \mathrm{M}$ berberine, the activities of caspase- $8,-9$ and -3 were determinated by flow cytometry. The results are shown in Fig. 5a-c, which indicates that berberine promoted the activation of caspase- $8,-9$ and -3 in C6 cells and these effects were time-dependent.

Berberine affects the apoptosis associated proteins in C6 cells. Based on our results, which show that berberine causes strong apoptotic death (Fig. 2a and b), in order to examine whether or not berberine induced apoptosis in C6 cells through caspase-dependent or -independent pathways, cells were treated with $100 \mu \mathrm{M}$ berberine for various time periods before harvesting for Western blotting examination. The results are shown in Fig. 6a-d. Results indicated that berberine promoted the expression of Wee1 (Fig. 6a), Fas/CD95 (Fig. 6b), cytochrome $c$ and Bax (Fig. 6c), GADD153 and GRP78 (Fig. 6d), but it decreased the levels of cyclin B, CDK1 and cdc25c (Fig. 6a), pro-caspase-8 and pro-caspase-3 (Fig. 6b), pro-caspase-9 and Bcl-2 (Fig. 6c) and pro-caspase-12 (Fig. 6d).

As shown in Fig. $6 \mathrm{~b}$ and $\mathrm{c}$, treatment of cells with berberine resulted in a time-dependent decrease in procaspase- $9,-3$ and -8 with the strongest effect at 24,48 and $72 \mathrm{~h}$, suggesting a possible involvement of caspase activation in the apoptotic effect of berberine. Fig. $4 \mathrm{~b}$ shows that berberine decreased the levels of $\Delta \Psi_{m}$ and we also found that the pro-apoptotic protein Bax was increased and the antiapoptotic protein $\mathrm{Bcl}-2$ was decreased. The ratio of $\mathrm{Bax} / \mathrm{Bcl}-2$ is associated with the levels of $\Delta \Psi_{m}$ and the results showed that berberine promoted the levels of Bax but decreased the levels of Bcl-2 which led to changes of $\Delta \Psi_{m}$.

\section{Discussion}

Although berberine is widely used as an anti-inflammatory, anti-diarrhea medicine and it may be used as a clinical application in cancer therapy in future, a clear understanding of its mechanisms of action is not known. Therefore, we showed that berberine induced cell cycle arrest and apoptosis in C6 rat glioma cells in a dose- and time-dependent manner. 
a.
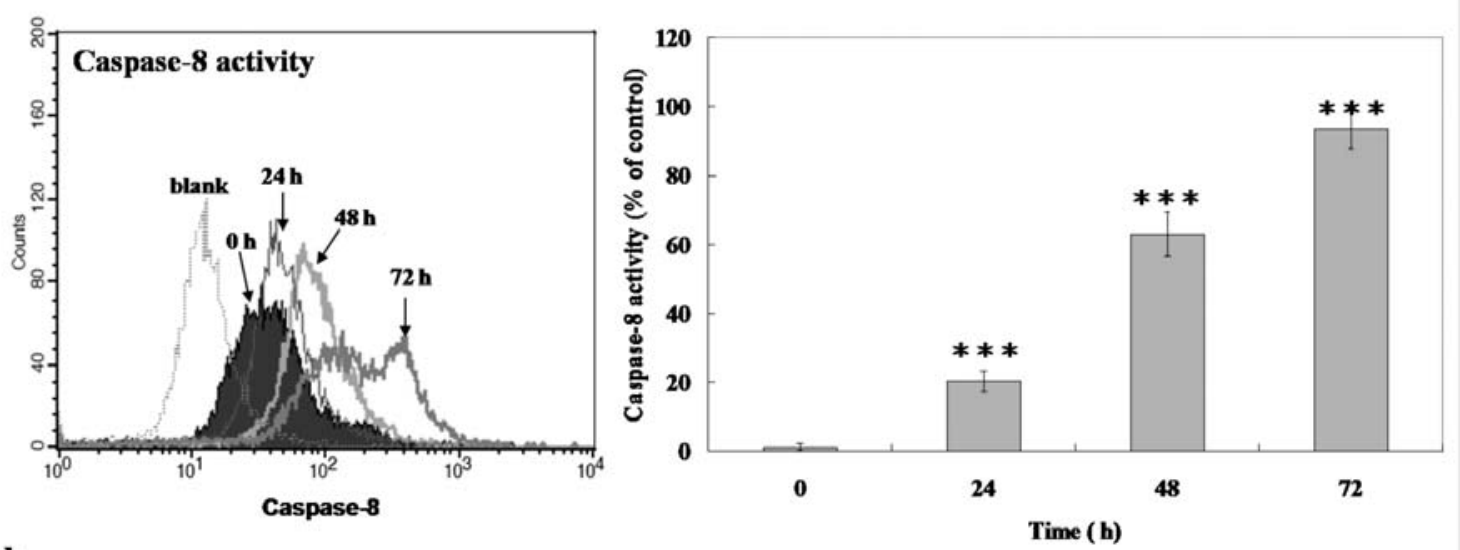

b.
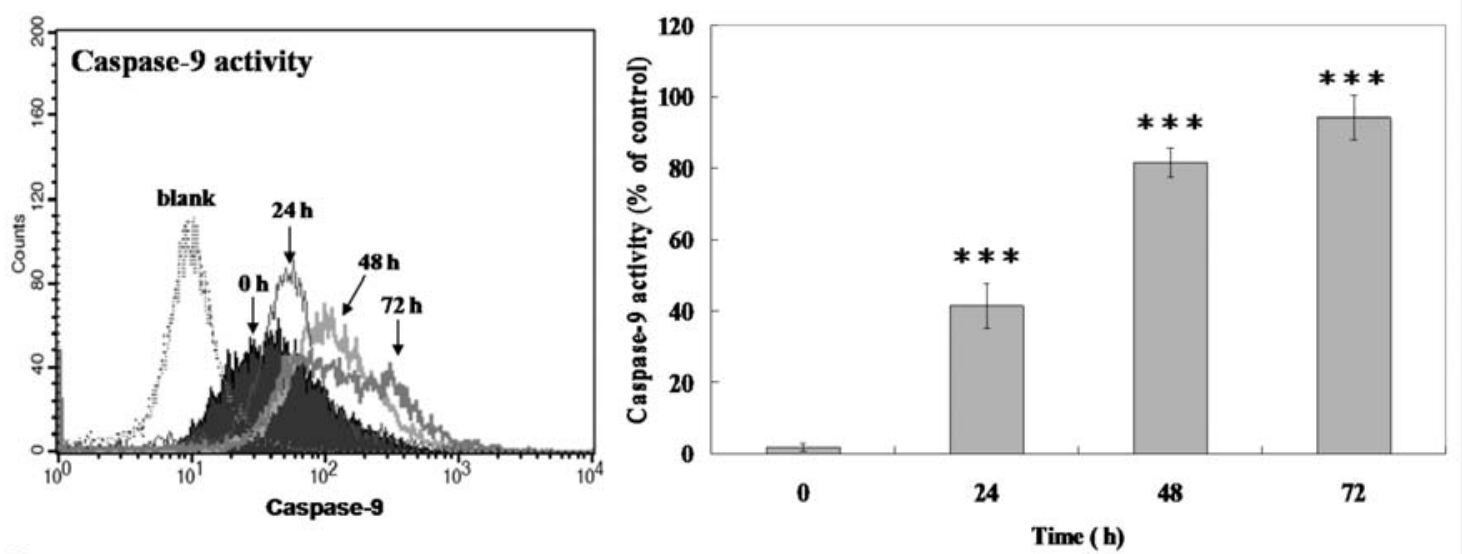

c.
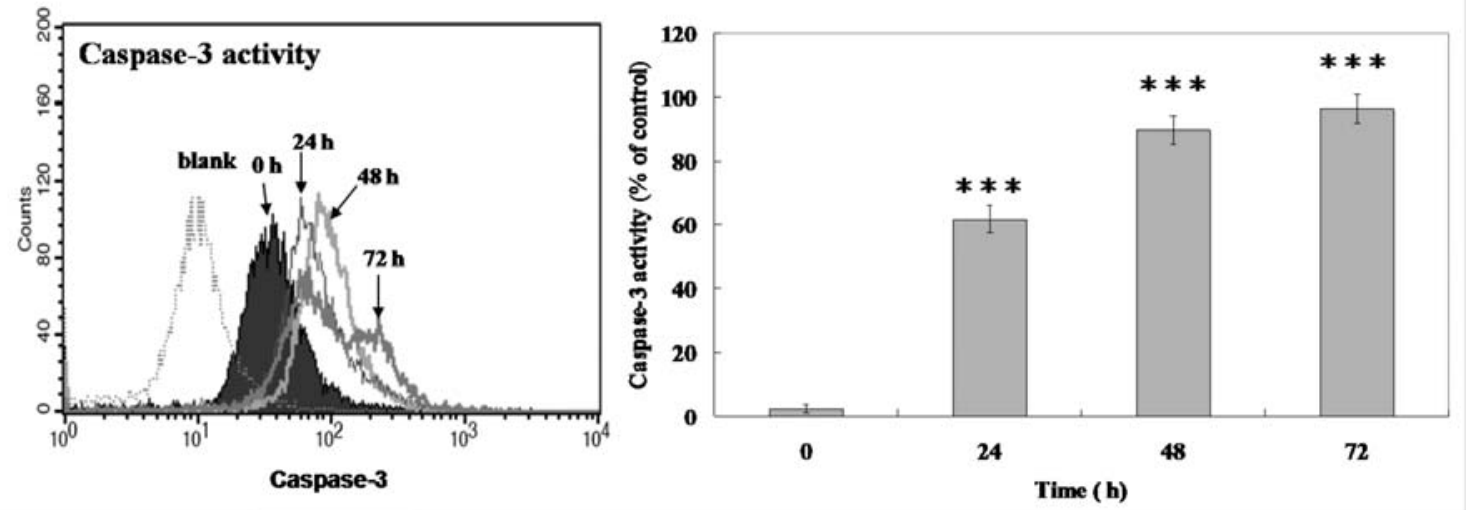

Figure 5. Berberine affects the levels of caspase-3, -8 and -9 activity of C6 cells. Cells were incubated with $100 \mu \mathrm{M}$ berberine for $0,24,48$ and $72 \mathrm{~h}$ and cells were harvested from each sample for caspase-3 (a), -8 (b) and -9 (c) determinations as described in Materials and methods. Caspase-3, -8 and -9 activities were determined and analyzed according to the manufacturer's instructions. Each point is mean $\pm \mathrm{SD}$ of three experiments. ${ }^{* * *} \mathrm{P}<0.001$.

Berberine only induced $\mathrm{G} 2 / \mathrm{M}$ arrest when berberine concentration was increased to $50 \mu \mathrm{M}$. Berberine acts as a potent genotoxicant as it induces a remarkable accumulation of DNA damage based on the results from Comet assay (Fig. 3a).

It is well known that berberine exhibits a tumor-inhibitory effect. We also gained some understanding of how berberine caused the cell cycle arrest and apoptosis in some cancer cells. Those effects are cell type-dependent. Other previous studies showed that berberine had no cytotoxic, mutagenic or recombinogenic activity on non-dividing cells from
Saccharomyces cerevisiae, but it induced significant cytotoxic and cytostatic effects on dividing cells (26).

It remains to be determined how berberine induces DNA damage. Some studies suggest that berberine may either directly bind duplex DNA by intercalation (27-30) or inflict DNA damage indirectly by its interaction with topoisomerases I and II (28,31-33). Other investigators also showed that berberine at $150 \mathrm{mg} / \mathrm{ml}$ was able to induce the rate of sister chromatid exchanges, which reflects homologous recombination repair, by several fold (34). 
a.

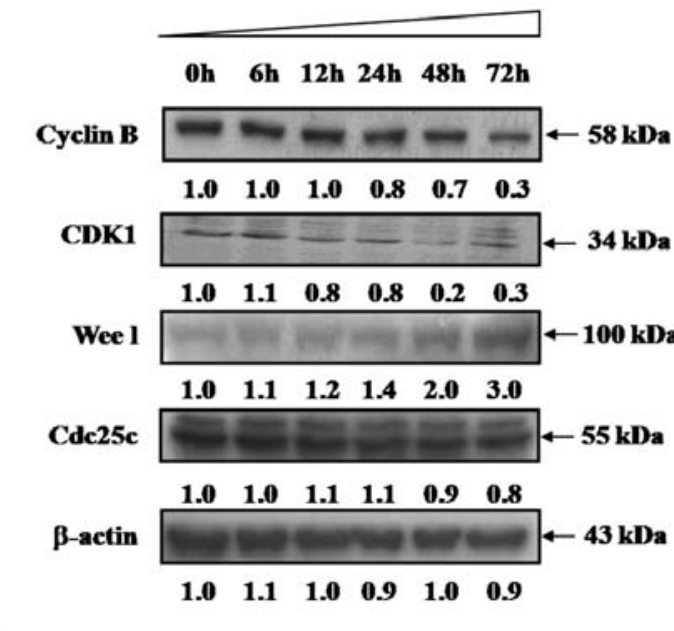

c.

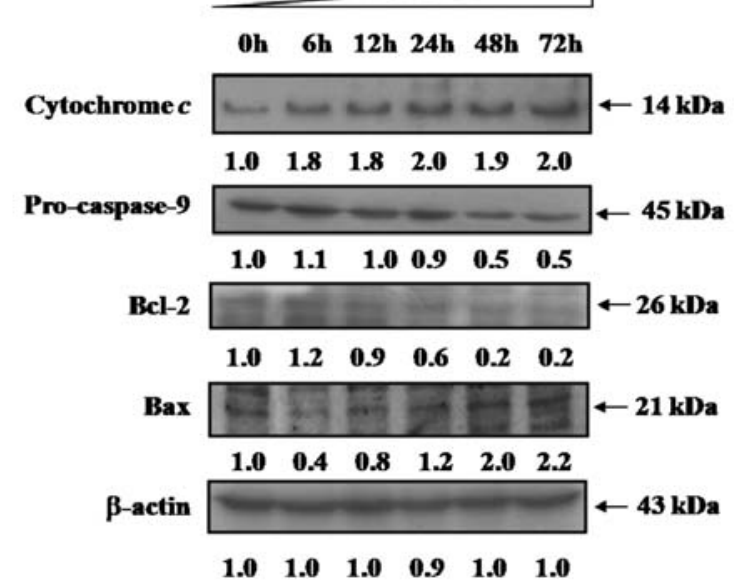

b.

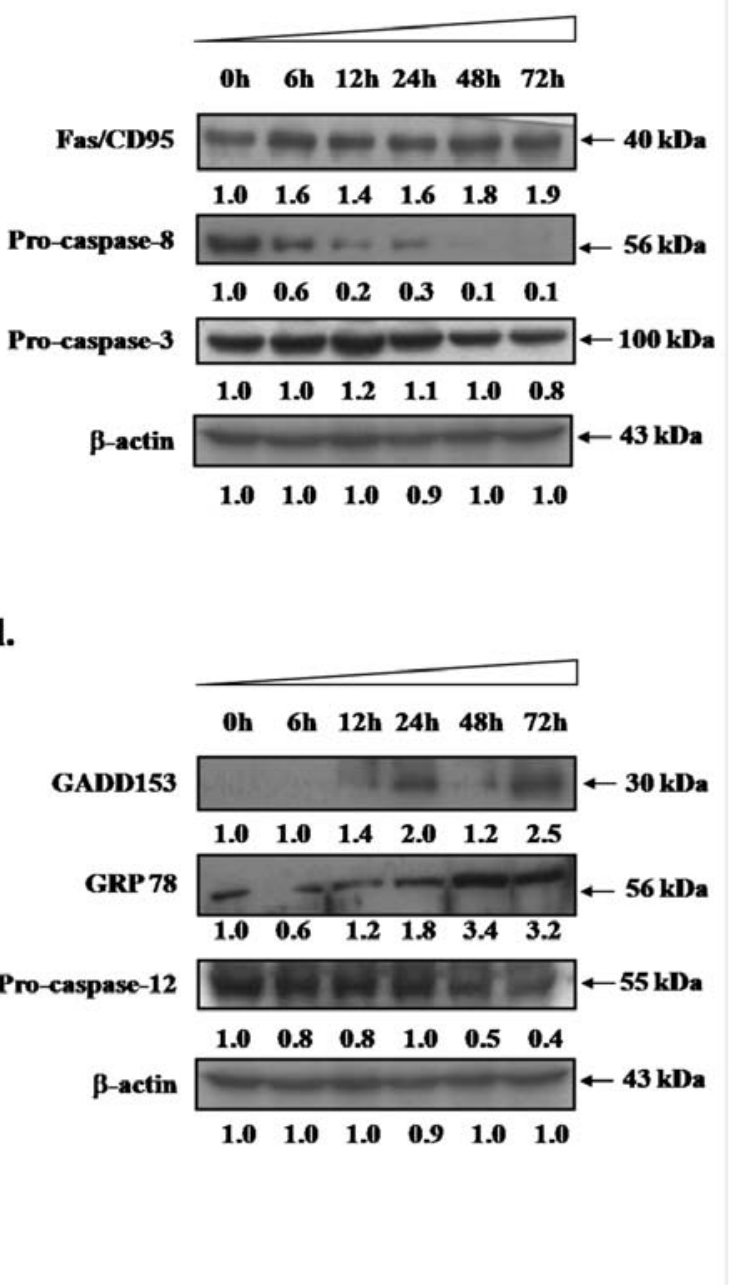

Figure 6. Berberine affects the apoptotic associated proteins in C6 cells. A total of $5 \times 10^{5} \mathrm{C} 6$ cells $/ \mathrm{ml}$ were treated with $100 \mu \mathrm{M}$ berberine for $0,6,12$ and $24 \mathrm{~h}$. Cells were harvested from each sample and associated proteins were determined by Western blotting. Cyclin B, CDK1, Wee1 and Cdc25c (a), Fas/CD95, procaspase-8 and -3 (b), cytochrome $c$, caspase-9, Bcl-2 and Bax (c), GADD153, GRP 78 and pro-caspase-12 (d) expression levels were examined using sodium dodecylsulfate polyacrylamide gel electrophoresis (SDS-PAGE) and Western blotting as described in Materials and methods.

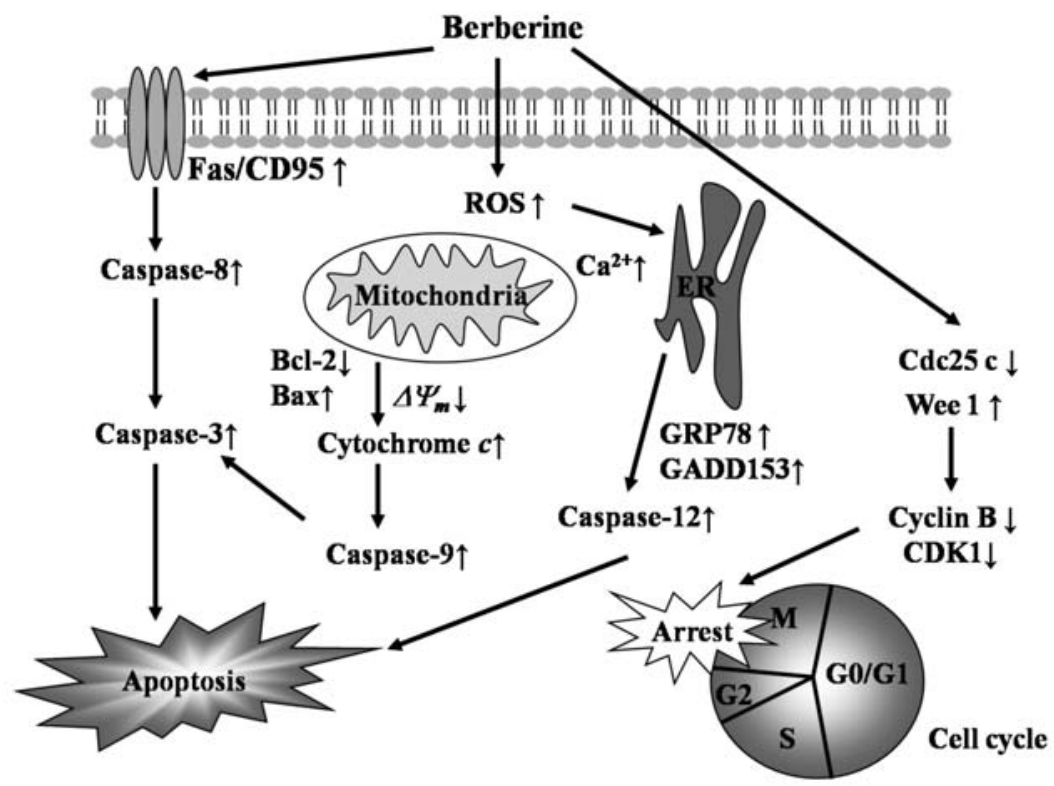

Figure 7. The possible signaling pathway of berberine induced cell cycle arrest and apoptosis in C6 rat glioma cells. Schematic diagram shows berberineinduced signaling concentration on activation of the apoptotic machinery in C6 cells. 
Our results showed that berberine induced $\mathrm{G} 2 / \mathrm{M}$ arrest in C6 cells through the inhibition of cyclin B, CDK1 and cdc 25c but promoted the levels of Wee1 (Fig. 6a) and it seems to be p53-dependent because our Western blotting also showed that berberine promoted the levels of p53 (data not shown). However, other studies showed that berberine caused p53dependent G1 arrest and it can also induce p53-independent $\mathrm{G} 2 / \mathrm{M}$ arrest. G2/M arrest also occurred in other cell lines in response to berberine and other treatments $(35,36)$. It has also been reported that the down-regulation of cyclin B1 and upregulation of Wee1 are associated with berberine-induced $\mathrm{G} 2 / \mathrm{M}$ arrest in leukemia cells (36), and indicated that $\mathrm{p} 27^{\mathrm{KIP} 1}$ plays a critical role in the $\mathrm{G} 2$ restriction point $(37,38)$. Thus, proteins responsible for berberine-induced $\mathrm{G} 2$ arrest in $\mathrm{C} 6$ cells remain to be identified.

Our findings showed that berberine can cause remarkable DNA damage in cultured cells via ROS production and it also showed ER stress due to the increased levels of GADD153 and GRP78 which are the hallmarks of ER stress followed by the release of $\mathrm{Ca}^{2+}$ from ER. This study also showed that berberine changes the ratio of Bax/Bcl-2 which led to dysfunction of mitochondria followed by the cytochrome $c$ release, caspase- 9 and -3 activations, causing apoptosis. Overall, this is summarized in Fig. 7. Berberine may, through the Fas/CD95 receptor, cause the signaling pathway for apoptosis. An examination of tissue distribution of berberine in vitro and its correlation to the level of DNA damage, apoptosis and cell death in a corresponding tissue would provide invaluable insight into its genetic safety.

\section{Acknowledgements}

This study was supported by grants CMU96-087 and CMU97-086 and CMU97-087 from China Medical University, Taichung, Taiwan.

\section{References}

1. Tan S, Sagara Y, Liu Y, Maher P and Schubert D: The regulation of reactive oxygen species production during programmed cell death. J Cell Biol 141: 1423-1432, 1998.

2. Ikeda K, Kajiwara K, Tanabe E, et al: Involvement of hydrogen peroxide and hydroxyl radical in chemically induced apoptosis of HL-60 cells. Biochem Pharmacol 57: 1361-1365, 1999

3. Muller I, Niethammer D and Bruchelt G: Anthracycline-derived chemotherapeutics in apoptosis and free radical cytotoxicity (Review). Int J Mol Med 1: 491-494, 1998.

4. Kroemer $\mathrm{G}$ and de The $\mathrm{H}$ : Arsenic trioxide, a novel mitochondriotoxic anticancer agent? J Natl Cancer Inst 91: 743-745, 1999.

5. Craig WJ: Health-promoting properties of common herbs. Am J Clin Nutr 70: 491S-499S, 1999.

6. Craig WJ: Phytochemicals: guardians of our health. J Am Diet Assoc 97: S199-S204, 1997.

7. Seth SD and Sharma B: Medicinal plants in India. Indian J Med Res 120: 9-11, 2004

8. Fukuda K, Hibiya Y, Mutoh M, Koshiji M, Akao S and Fujiwara $\mathrm{H}$ : Inhibition of activator protein 1 activity by berberine in human hepatoma cells. Planta Med 65: 381-383, 1999.

9. Takase H, Yamamoto K, Ito K and Yumioka E: Pharmacological studies on antidiarrheal effects of berberine and geranii herba. Nippon Yakurigaku Zasshi 102: 101-112, 1993.

10. Huang WM, Wu ZD and Gan YQ: Effects of berberine on ischemic ventricular arrhythmia. Zhonghua Xin Xue Guan Bing Za Zhi 17: 300-3319, 1989 .
11. Fukuda K, Hibiya Y, Mutoh M, Koshiji M, Akao S and Fujiwara H: Inhibition by berberine of cyclooxygenase-2 transcriptional activity in human colon cancer cells. J Ethnopharmacol 66: 227-233, 1999 .

12. Lin JG, Chung JG, Wu LT, Chen GW, Chang HL and Wang TF: Effects of berberine on arylamine $\mathrm{N}$-acetyltransferase activity in human colon tumor cells. Am J Chin Med 27: 265-275, 1999.

13. Nishino H, Kitagawa K, Fujiki H and Iwashima A: Berberine sulfate inhibits tumor-promoting activity of teleocidin in twostage carcinogenesis on mouse skin. Oncology 43: 131-134, 1986.

14. Kim SA, Kwon Y, Kim JH, Muller MT and Chung IK: Induction of topoisomerase II-mediated DNA cleavage by a protoberberine alkaloid, berberrubine. Biochemistry 37: 1631616324, 1998.

15. Wang LK, Rogers BD and Hecht SM: Inhibition of topoisomerase I function by coralyne and 5,6-dihydrocoralyne. Chem Res Toxicol 9: 75-83, 1996.

16. Mantena SK, Sharma SD and Katiyar SK: Berberine inhibits growth, induces G1 arrest and apoptosis in human epidermoid carcinoma A431 cells by regulating Cdki-Cdk-cyclin cascade, disruption of mitochondrial membrane potential and cleavage of caspase 3 and PARP. Carcinogenesis 27: 2018-2027, 2006.

17. Yu FS, Yang JS, Lin HJ, et al: Berberine inhibits WEHI-3 leukemia cells in vivo. In Vivo 21: 407-412, 2007.

18. Lin CC, Yang JS, Chen JT, et al: Berberine induces apoptosis in human HSC-3 oral cancer cells via simultaneous activation of the death receptor-mediated and mitochondrial pathway. Anticancer Res 27: 3371-3378, 2007

19. Lin JP, Yang JS, Wu CC, et al: Berberine induced downregulation of matrix metalloproteinase-1, -2 and -9 in human gastric cancer cells (SNU-5) in vitro. In Vivo 22: 223-230, 2008.

20. Lin SS, Huang HP, Yang JS, et al: DNA damage and endoplasmic reticulum stress mediated curcumin-induced cell cycle arrest and apoptosis in human lung carcinoma A-549 cells through the activation caspases cascade- and mitochondrial-dependent pathway. Cancer Lett (In prss).

21. Lee JH, Li YC, Ip SW, et al: The role of $\mathrm{Ca}^{2+}$ in baicalein-induced apoptosis in human breast MDA-MB-231 cancer cells through mitochondria- and caspase-3-dependent pathway. Anticancer Res 28: 1701-1711, 2008.

22. Lin YT, Yang JS, Lin HJ, et al: Baicalein induces apoptosis in SCC-4 human tongue cancer cells via a $\mathrm{Ca}^{2+}$-dependent mitochondrial pathway. In Vivo 21: 1053-1058, 2007.

23. Wang SC, Chung JG, Chen $\mathrm{CH}$ and Chen SC: 2- and 4-Aminobiphenyls induce oxidative DNA damage in human hepatoma (Hep G2) cells via different mechanisms. Mutat Res 593: 9-21, 2006.

24. Chen JC, Lu KW, Tsai ML, et al: Gypenosides induced G0/G1 arrest via CHk2 and apoptosis through endoplasmic reticulum stress and mitochondria-dependent pathways in human tongue cancer SCC-4 cells. Oral Oncol 45: 273-283, 2009.

25. Chuang JY, Tsai YY, Chen SC, Hsieh TJ and Chung JG: Induction of G0/G1 arrest and apoptosis by 3-hydroxycinnamic acid in human cervix epithelial carcinoma (HeLa) cells. In Vivo 19: 683-688, 2005

26. Pasqual MS, Lauer CP, Moyna P and Henriques JA: Genotoxicity of the isoquinoline alkaloid berberine in prokaryotic and eukaryotic organisms. Mutat Res 286: 243-252, 1993.

27. Ihmels H, Faulhaber K, Vedaldi D, Dall'Acqua F and Viola G: Intercalation of organic dye molecules into double-stranded DNA. Part 2: the annelated quinolizinium ion as a structural motif in DNA intercalators. Photochem Photobiol 81: 1107-1115, 2005.

28. Li TK, Bathory E, LaVoie EJ, et al: Human topoisomerase I poisoning by protoberberines: potential roles for both drug-DNA and drug-enzyme interactions. Biochemistry 39: 7107-7116, 2000.

29. Krey AK and Hahn FE: Berberine: complex with DNA. Science 166: 755-757, 1969.

30. Davidson MW, Lopp I, Alexander S and Wilson WD: The interaction of plant alkaloids with DNA. II. Berberinium chloride. Nucleic Acids Res 4: 2697-2712, 1977.

31. Makhey D, Gatto B, Yu C, Liu A, Liu LF and LaVoie EJ: Coralyne and related compounds as mammalian topoisomerase I and topoisomerase II poisons. Bioorg Med Chem 4: 781-791, 1996. 
32. Gatto B, Sanders MM, Yu C, et al: Identification of topoisomerase I as the cytotoxic target of the protoberberine alkaloid coralyne. Cancer Res 56: 2795-2800, 1996.

33. Kobayashi Y, Yamashita Y, Fujii N, et al: Inhibitors of DNA topoisomerase I and II isolated from the Coptis rhizomes. Planta Med 61: 414-418, 1995.

34. Zhang RX, Dougherty DV and Rosenblum ML: Laboratory studies of berberine used alone and in combination with 1,3-bis (2-chloroethyl)-1-nitrosourea to treat malignant brain tumors. Chin Med J (Engl) 103: 658-665, 1990.

35. Lin JP, Yang JS, Lee JH, Hsieh WT and Chung JG: Berberine induces cell cycle arrest and apoptosis in human gastric carcinoma SNU-5 cell line. World J Gastroenterol 12: 21-28, 2006.
36. Lin CC, Lin SY, Chung JG, Lin JP, Chen GW and Kao ST: Down-regulation of cyclin B1 and up-regulation of Wee1 by berberine promotes entry of leukemia cells into the G2/M-phase of the cell cycle. Anticancer Res 26: 1097-1104, 2006.

37. Payne SR, Zhang S, Tsuchiya K, et al: p27kip1 deficiency impairs $\mathrm{G} 2 / \mathrm{M}$ arrest in response to DNA damage, leading to an increase in genetic instability. Mol Cell Biol 28: 258-268, 2008.

38. Foijer F, Delzenne-Goette E, Dekker M and Te Riele H: In vivo significance of the G2 restriction point. Cancer Res 67: 9244-9247, 2007. 